\title{
Shock events and flood risk management: a media analysis of the institutional long-term effects of flood events in the Netherlands and Poland
}

\author{
Maria Kaufmann ${ }^{1}$, Jakub Lewandowski $^{2}$, Adam Choryński $^{2}$ and Mark Wiering ${ }^{1}$
}

\begin{abstract}
Flood events that have proven to create shock waves in society, which we will call shock events, can open windows of opportunity that allow different actor groups to introduce new ideas. Shock events, however, can also strengthen the status quo. We will take flood events as our object of study. Whereas others focus mainly on the immediate impact and disaster management, we will focus on the long-term impact on and resilience of flood risk governance arrangements. Over the last 25 years, both the Netherlands and Poland have suffered several flood-related events. These triggered strategic and institutional changes, but to different degrees. In a comparative analysis these endogenous processes, i.e., the importance of framing of the flood event, its exploitation by different actor groups, and the extent to which arrangements are actually changing, are examined. In line with previous research, our analysis revealed that shock events test the capacity to resist and bounce back and provide opportunities for adapting and learning. They "open up" institutional arrangements and make them more susceptible to change, increasing the opportunity for adaptation. In this way they can facilitate a shift toward different degrees of resilience, i.e., by adjusting the current strategic approach or by moving toward another strategic approach. The direction of change is influenced by the actors and the frames they introduce, and their ability to increase the resonance of the frame. The persistence of change seems to be influenced by the evolution of the initial management approach, the availability of resources, or the willingness to allocate resources.
\end{abstract}

Key Words: flood risk management; framing; institutional change; the Netherlands; resilience; Poland; shock event

\section{INTRODUCTION}

Flood risk is increasing; the probability of flooding is projected to increase because of climate change. The consequences of flooding are increasing because of ongoing socioeconomic development in flood-prone areas (Mitchell 2003, Klijn et al. 2012, Alfieri et al. 2015). Appropriate adaptation to those changes is regularly connected to an increase in resilience, i.e., the capacity of society (as a whole) to resist, to absorb and recover, and to adapt to hazards (see Hegger et al. 2016). In flood risk management (FRM), resilience is often connected to a diversification of strategies that address these different capacities (Table 1; Hegger et al. 2014).

Table 1. Flood risk strategies (cf. Hegger et al. 2014).

\begin{tabular}{cccccc}
\hline \hline Strategy & Prevention & Defense & Mitigation & Preparation & Recovery \\
\hline Measures & $\begin{array}{c}\text { Prohibition } \\
\text { of } \\
\text { construction }\end{array}$ & $\begin{array}{c}\text { Dikes, } \\
\text { retention } \\
\text { basins }\end{array}$ & $\begin{array}{c}\text { Flood- } \\
\text { adapted } \\
\text { infrastruc- } \\
\text { ture }\end{array}$ & $\begin{array}{c}\text { Emergency } \\
\text { planning }\end{array}$ & Insurance \\
\hline
\end{tabular}

To increase resilience, existing flood risk governance arrangements (FRGAs) might need to be adjusted. These FRGAs are the institutional structures and processes that guide and restrain collective activities of a society to regulate, reduce, or control risks (Renn et al. 2011). Sjöstedt (2015) argues that the endogenous, institutional dynamics of this adjustment tend to receive little attention. We address this gap by focusing on crisisdriven institutional dynamics (Rosenthal and 't Hart 1998). Flood events may stabilize policies (cf. Birkland 1998, Driessen and De Gier 1999, Boin et al. 2009), but also cause catalytic changes by accelerating the policy change process (cf. Baumgartner and Jones 1993, Kingdon 1995, Lowry 2006). For example, flood events in
England opened windows of opportunity that accelerated the implementation of pre-event ideas (Johnson et al. 2005, PenningRowsell et al. 2006).

We aim to analyze the influence of shock events on the transformation toward different forms of resilience. However, the relation between shock events and resilience has received little attention in the resilience literature until now (Olsson et al. 2006, Chaffin et al. 2014) with a number of exceptions (e.g., Solecki and Rosenzweig 2014). To analyze the effect of the shock event on the FRGA, we chose a framing perspective. Research on framing is widely spread to analyze political mobilization and social movements (e.g., Snow and Benford 1988, Dewulf et al. 2005, Vink et al. 2013, Metze 2014), yet combining exogenous shock events with an endogenous framing perspective to understand institutional change is a relatively new approach.

We explore this relation by analyzing two case study countries: the Netherlands and Poland. Focusing on only two countries enables us to conduct an in-depth analysis of the framing processes and institutional dynamics. Compared with other countries in the research project STARFLOOD, the Netherlands and Poland show the following similarities: a strong role for government, a traditional focus on a hydro-engineering flood defense approach, and the occurrence of flood events with effect on the FRGA. Differences between the two countries include the degree of institutionalization of the FRGA and the resource availability for FRM (Kaufmann et al. 2016, Matczak et al. 2016). By having comparable management approaches as starting points, but different degrees of institutionalization, we can shed more light on the institutional dynamics triggered by the shock event.

Our aim is to contribute to the resilience and flood risk governance literature by analyzing the role of shock events on policy 
evolution. Therefore, we conducted a longitudinal analysis that investigated the influence of events on FRGAs. We distinguish between short-term (from a few months up to 5 years after the shock event), midterm (5-10 years), and long-term effect (15-20 years). We have analyzed the following research questions: How have (near) flood events been framed in the Netherlands and Poland between 1990 and 2014 at the national level? What are the most dominant frames that can be found in the media and in political documents? What factors facilitated the resonance of those frames, including framing strategies? What is the role of the existing governance arrangement in facilitating or hampering change? How did the event affect national governance arrangements? How persistent is this change?

\section{CONCEPTUAL FRAMEWORK}

To understand the effect of events on FRGAs, we developed a conceptual framework that links events to both an (agencyfocused) framing perspective and a more (structure-based) institutional perspective (cf. Giddens 1984). We used these concepts to guide our empirical research.

We understand a shock event as a focusing event (Kingdon 1995, Birkland 1998) that has created considerable stress waves in a society. Birkland defines a potential focusing event as "an event that is sudden; relatively uncommon; can be reasonably defined as harmful or revealing the possibility of potentially greater future harms; has harms that are concentrated in a particular geographical area or community of interest; and that is known to policy makers and the public simultaneously" (1998:54). That implies that such an event does not necessarily need to cause harm, but already its potential to cause harm is sufficient to cause institutional change. With shock events we want to emphasize the fact that the event has already had a certain effect (created shock waves in society) on the media, the politicians, and the public, and this is the starting point to assess what kind of effect the event had, and to what extent it is a long lasting effect. We obviously make intensive use of the vocabulary of Kingdon (1995) who sees policy change and dynamics in terms of separate streams of problems, policies, and politics that come together at critical times. "Solutions become joined to problems, and both of them are joined to favorable political forces. This coupling is most likely when policy windows - opportunities for pushing pet proposals or conceptions of problems - are open" (Kingdon 1995:20). Focusing events like crisis or disaster call attention to the problem (or problems), change the perception of the problem, though perhaps temporary, change the urgency of political action, and possibly change policies in the long term. Policy windows can be of short duration, but can also cast long shadows (Zahariadis 2014). Events can function as early warnings, that might announce structural problems, and aggregated disasters can have important public policy effects (Kingdon 1995), but problems could also fade away again, after people may feel they have solved the problem, after they were addressed by government, through (perhaps symbolic) legislation, or sometimes merely because people do not welcome suggested changes (climate change and reducing private emissions) or lose their interest and enthusiasm for addressing the problem (Kingdon, 1995). In any case, policy windows can open, but also close at a certain point in time. It is important to focus on what happens in the meantime, and one important strategy of policy entrepreneurs is the meaningmaking and framing processes following the event.
The simple occurrence of an event is not sufficient for institutional change. Big or small events happen all the time. It is the way actors frame the event as a disaster that decides its institutional effect. Again, events are always framed in some way, either to give them meaning or to classify them as meaningless (Crotty 1998). Framing describes a schema that allows individuals "to locate, perceive, identify and label" occurrences in life (Goffman 1974:21). The way actors frame an event is determined by the overarching discourses that influence how actors understand the world (Van den Brink 2009). In the realm of policies and politics, this means actor groups differ in the way they frame a shock event to alter the political support for policies and further their own ideas. A framing contest takes place between status quo players that resist or aim to contain policy change, and change agents that press for a policy paradigm shift or incremental reform (Boin et al. 2009). We apply Snow and Benford's (1988) core framing tasks to identify and analyze the activities of different actor coalitions: diagnostic framing, which is the process of identifying the problem, connected causalities, and the responsible actors to blame; prognostic framing, which is the process of proposing a general solution to that problem; and motivational framing, which is the process of offering action frames, in the form of concrete policy options (cf. Lindekilde 2014, Crabbé et al. 2015; Table 2). In other words, framing a shock event enables the actor to link the problem stream to the solution (policy) stream, a process, which is influenced by the political stream.

Table 2. Description of the core framing tasks (cf. Lindekilde 2014).

\begin{tabular}{lll}
\hline \hline Diagnostic framing & Prognostic framing & Motivational framing \\
\hline $\begin{array}{l}\text { Identification of the } \\
\text { problem and the } \\
\text { attribution of blame } \\
\text { and causality }\end{array}$ & $\begin{array}{l}\text { Proposed solution to } \\
\text { the identified problem. } \\
\text { The indication of } \\
\text { strategies, tactics, and } \\
\text { goals }\end{array}$ & $\begin{array}{l}\text { Indication of policy } \\
\text { options }\end{array}$ \\
$\begin{array}{l}\text { Example: } \\
\text { "People living in the } \\
\text { flood plain is the } \\
\text { reason for severe } \\
\text { damage." }\end{array}$ & $\begin{array}{l}\text { "We need to leave the } \\
\text { floodplains, otherwise } \\
\text { the number of } \\
\text { casualties will }\end{array}$ & $\begin{array}{l}\text { "Municipalities should } \\
\text { have the possibility to } \\
\text { force people to relocate } \\
\text { increase." }\end{array}$ \\
\hline
\end{tabular}

The question arises how actors can further their preferred solution, i.e., increase the resonance and credibility of their frame. This can be done by aligning their frames to the discursive opportunity structure, i.e., hegemonic discourses, or to frames belonging to hegemonic discourses, that are seen as sensible and legitimate. For example, climate change is a widely accepted discourse, so framing an event as a warning of climate change will increase its resonance. The discursive opportunity structure can be more stable, i.e., hegemonic over a long period, or more volatile over a shorter time. Correspondingly, the resonance of a frame might be more long-lasting or temporary (McCammon et al. 2007). From the literature we can identify different alignment strategies (Benford and Snow 2000). Frame bridging is defined by Benford and Snow (2000:624) as the "linking of two or more ideologically congruent but structurally unconnected frames regarding a particular issue," e.g., linking the frame to other popular trends, like sustainability or climate change. Frame amplification is the idealization, embellishment, or strengthening 
of existing values and beliefs (Benford and Snow 2000), e.g., reinforcing values of safety. Frame extension is the broadening of the frame to incorporate concerns important for potential support, e.g., combining the protection of fish with the protection of beavers. Frame transformation is the changing of old understandings and meanings by generating new meanings (Benford and Snow 2000), e.g., framing a dike, not in terms of safety, but in terms of adverse ecological impacts to delegitimize engineering approaches.

The framing of a shock event takes place within an existing governance arrangement. Arrangements can differ in their degree of stability and the corresponding susceptibility to change (Blowers and Leroy 2003, Boonstra 2004, Crabbé 2008, Mahoney and Thelen 2009). If a flood event is framed as a shock event, it opens up the arrangement by creating a window of opportunity that makes the arrangement more susceptible to new ideas and potential policy change. Windows can be of short duration, but can also cast long shadows. We apply the policy arrangement approach (PAA) to map out the key structures of the institutional arrangement preshock event, as well as the changes corresponding to the shock event. The PAA analyzes an institutional subsystem in terms of four dimensions: its formal and informal rules, the involved actor coalitions, their resource and power positions, and dominant policy discourses (Liefferink 2006, Wiering and Arts 2006). Thus, it facilitates the identification of policy change: Is policy change mainly of a rhetorical/symbolic nature, or does it affect one or more of the organizational dimensions, i.e., the actor constellation and the rules or resources-dimension (Liefferink 2006, Wiering and Arts 2006)? The change can be more lastingly stabilized in the form of legislation or permanent authorities. It can also be more temporary in the form of short-term policy programs or interim working groups. Research steps are summarized in Figure 1.

Fig. 1. Research steps per event and per country. FRGA = flood risk governance arrangement.

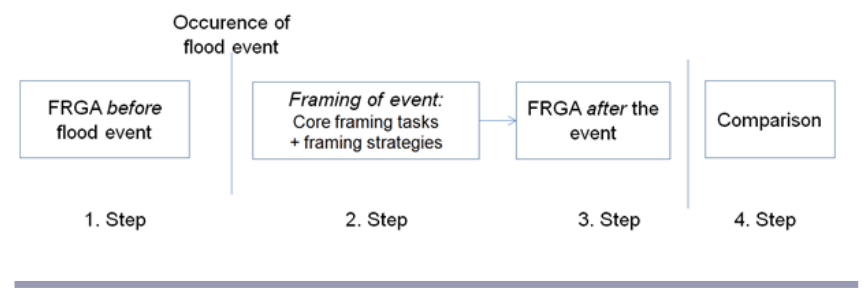

\section{METHODS}

\section{Case selection}

The influence of shock events on FRGAs was explored empirically in a comparative case study analysis of the Netherlands and Poland. In both countries, we chose particular shock events. For the Netherlands, it was the public debate surrounding the flood experience of 1993 and 1995. Both events occurred in such a short period of time that they were afterward often referred to in a combined way. In Poland, it was the political debate following the flood events of 1997 and 2010.

\section{Data selection}

The research is embedded into a broader research project: STARFLOOD. Within the project a longitudinal analysis of the dynamics in the FRGA in the Netherlands and Poland was carried out over a period of 25 years, which was deemed sufficient to assess long-term institutional change. This analysis consisted of an extensive literature study of legal and policy documents, over 40 semistructured interviews, and three regional case studies in both countries (Kaufmann et al. 2016, Matczak et al. 2016). It provided background information that supplements our understanding.

A media analysis was carried out to explore the discursive space and identify framing packages (see Gamson and Modigliani 1989). In the Dutch context we chose three national newspapers for our analysis, namely Trouw, $N R C$, and $A D$ which cover a broad political spectrum from socio-democratic, to liberal-academic, and to conservative. We used the database LexisNexis to search those newspapers for articles that included at least one of the following search terms (in Dutch): flooding, high water, evacuation, water nuisance, or dike breach, as well as one of these terms: Rhine, Meuse, or Waal, which are rivers in Europe. We chose search terms that yielded a wide range of newspaper articles and that were suitable for both countries. From 1992 to 1996 we analyzed articles every year, and afterward we adopted a two-year interval until 2014, for feasibility reasons. Figure 2 illustrates the number of analyzed articles per year. The effect of the shock event of 1995 produced the greatest number of articles.

Fig. 2. Number of articles per year in the Netherlands.

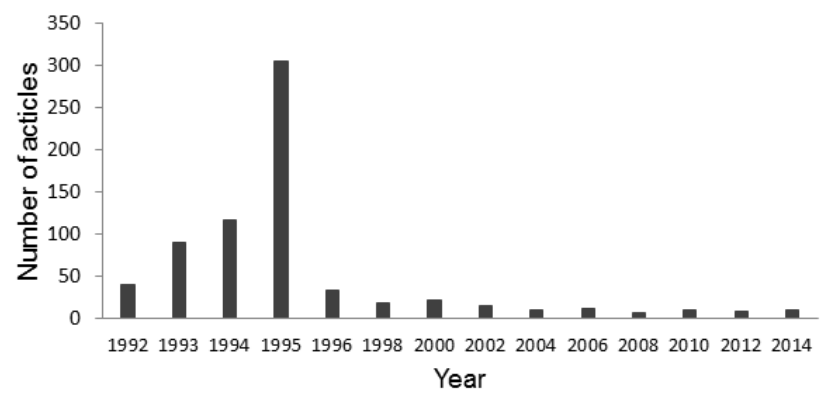

In Poland, we also worked with nationwide, digital newspaper archives. We chose the archive with the greatest number of records over the longest time period, i.e., 1993-2014. Only two newspapers were digitally available: Gazeta Wyborcza $(G W)$, a somewhat liberal newspaper, and Rzeczpospolita $(R Z)$, a more conservative newspaper. The keywords flood, Odra, and Vistula (rivers in Poland) identified the most relevant articles (Fig. 3). Having two instead of three newspapers was not seen as a problem as long as a broad political spectrum was covered.

Fig. 3. Number of articles per year in Poland.

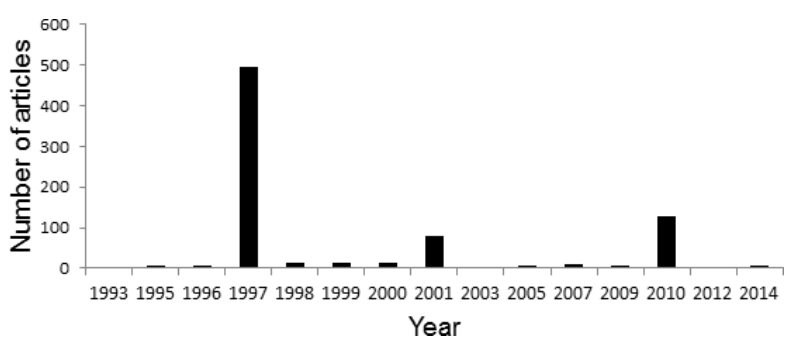


To improve the correspondence between a frame and the identified policy change, we also analyzed parliamentary discussions and policy documents. When using the parliamentary archives we searched with the same search terms as for the media analysis in both countries. Because of space constraints we focus on frames that are present in the media and the parliamentary documents at the national level.

\section{Data analysis}

On the basis of the core framing tasks, the material was coded. Thus, in a first step we coded the newspaper articles, and in a second step we coded the policy documents. We used the conceptual codes (see Table 1) deductively, but refined these initial codes inductively based on the empirical findings (like Lindekilde 2014). We differentiated between frames based on the core framing tasks and the FRM strategy they described (i.e., prevention, defense, mitigation, preparation, and recovery), or if they described a specific FRM measure within a strategy (e.g., private insurance or public compensation within the strategy of recovery), or if they described specific governance characteristics (e.g., public responsibility or private responsibility).

To systematize the analysis, we used software programs, atlas.ti in the Netherlands and nvivo in Poland. The use of different software programs was not seen as a problem because we applied the same conceptual codes. To increase the reproducibility, we decided to focus on the most dominant frames, i.e., the frames that came up most often in quotations, in both the media analysis and in the analysis of political documents.

\section{RESULTS}

\section{The Netherlands}

FRM in the Netherlands is traditionally characterized by a sectorbased, hydro-technical flood defense approach (Van de Ven 2004, Van Heezik 2006). This approach is highly institutionalized with safety standards and specialized governmental authorities (see Table 3; Van Rijswick and Havekes 2012). During the 1970s environmental concerns gained importance with actors advocating these ideas (Schwartz 1993, Disco 2002, Lintsen 2005). The policy concept "Integrated Water Management" was introduced in 1989 in "The 3rd National Policy Document on Water Management." It described a more ecological and comprehensive manner of water management including several policy sectors. Projects were developed to integrate nature and water development, e.g., Plan Stork (Plan Ooievaar, 1986) and Living Rivers (Levende Rivieren, 1992; Disco 2002, Van den Brink 2009).

Preceding the flood events, the media analysis revealed that the flood defense approach was increasingly criticized because of its negative effects on the environment and cultural (river) landscape, and adverse social impacts, i.e. destruction of settlements. Societal, environmental, and nature conservation groups opposed extensive dike strengthening in favor of cultural and environmental values. They appealed against dike strengthening by going, for example, to the European court forcing the application of Environmental Impact Assessment (EIA) when carrying out defense measures (Van Eten 1997). In contrast, the governmental water managers stressed the necessity of defense structures to provide safety, also along the rivers.
Table 3. Characteristics of the Dutch flood risk governance arrangement (FRGA) before the flood event of 1993.

\begin{tabular}{ll}
\hline \hline $\begin{array}{l}\text { Characteristics of } \\
\text { the FRGA }\end{array}$ & The Netherlands \\
\hline $\begin{array}{l}\text { Discourse } \\
\text { (hegemonic) }\end{array}$ & $\begin{array}{l}\text { Hydro-technical discourse ("Safety first! Engineering } \\
\text { measures offer protection") }\end{array}$ \\
Rules & $\begin{array}{l}\text { Strict national safety standards in policy } \\
\text { Actors }\end{array}$ \\
& $\begin{array}{l}\text { Specialized national and regional water managers } \\
\text { High level of expertise }\end{array}$ \\
Power/Resources & National subsidies and specialized regional taxes \\
\hline
\end{tabular}

Politically, flooding was not a high priority. Nevertheless, an advisory committee (Boertien I), was installed to study the future of FRM. The committee stressed the importance of public support, the preservation of LNC-values (landscape, nature, and culture), and the need for obligatory EIA. It supported new ideas of integrating water and nature development, but stated that dike reinforcement was always necessary (Commissie Boertien I 1993).

First shock event: flood of December 1993

In December 1993, high water levels in the Meuse and Rhine led to flooding in the southern province of Limburg resulting in the evacuation of 8000 people and $€ 122$ million damages (Van den Ven 2004, Warner 2008). Table 4 summarizes three dominant frames that were found in the analysis: "prodike strengthening" opposing "additional study" and "spatial planning." Marginally, emergency management and private insurance were also discussed, but they were mentioned less often, which implies little resonance. Furthermore, they were either limited to a more localized operational issue and not a national policy issue, i.e., emergency management, or they were only peripherally connected to flooding, and more the result of other events, e.g., a discussion on insurance as a reaction to an earthquake.

The media analysis revealed that affected citizens, regional governments, and regional water authorities framed the event as a serious crisis demanding immediate action in the form of dike strengthening. They blamed the interest groups that delayed dike strengthening (frame: prodike strengthening). However, the resonance of the frame was limited because the flood event stayed a regional issue. Correspondingly, Rijkswaterstaat (the national water authority) and the Minister of Transport and Water framed the flood event as a minor nuisance with only material damages. Furthermore, scientific experts stressed that the hydroengineering situation along the Meuse was difficult to manage. Because of the gravel soil it would be costly, more costly than the current damages, or potentially even impossible to prevent water passing under the dike. Further research was needed to analyze the feasibility and costs of management measures (frame: additional study). The resonance of the frame was increased because these experts had a high credibility and connections to the Minister of Transport and Water, but also in the media this frame was supported. Additionally, the legitimacy of local actors, like municipalities and the province, was decreased by the media and national politicians, among others the Minister of Transport and Water, who framed the event as a shortcoming of spatial planners that permitted the construction in the flood plain causing the event (frame: spatial planning shortcoming). 
Table 4. Overview of frames identified after the flood of 1993 with representative quotations $(1993-1995)$. FRM = flood risk management.

\begin{tabular}{|c|c|c|c|}
\hline Frames & Diagnostic & Prognostic & Motivational \\
\hline $\begin{array}{l}\text { Additior } \\
\text { e.g., Nat }\end{array}$ & $\begin{array}{l}1 \text { study, } \\
\text { nal level water managers, media (NRC), historic, } \\
\text { Event was water nuisance, less a serious crisis. } \\
\text { National Water manager: "We don't call it } \\
\text { flooding. The damage of a dike breach is } 15 \\
\text { billion Guilders, but in Limburg the damage } \\
\text { was only } 100 \text { million Guilders." (Trouw, } 7 \\
\text { December 1994) }\end{array}$ & $\begin{array}{l}\text { insurance } \\
\text { Difficult situation, feasibility of constructing } \\
\text { dikes is limited in Limburg. } \\
\text { Minister: "It is impossible to prevent flooding } \\
\text { on the Meuse completely. Local problems } \\
\text { could be solved, but that would increase the } \\
\text { water level at other places." (political } \\
\text { discussions, } 9 \text { March 1994) }\end{array}$ & $\begin{array}{l}\text { Setting up committee to investigate possibilities } \\
\text { of FRM along the Meuse. } \\
\text { Minister: "This committee must give advice } \\
\text { regarding the possible measures to limit water } \\
\text { nuisance." (political discussions, } 9 \text { March 1994) }\end{array}$ \\
\hline $\begin{array}{l}\text { Prostruc } \\
\text { e.g., regi }\end{array}$ & $\begin{array}{l}\text { Iral defense, } \\
\text { hal water managers, some politicians } \\
\text { Serious event, due to lack of dike strengthening } \\
\text { because of discussions and nature protests. } \\
\text { Regional water managers: "All the discussions } \\
\text { cause delay in the implementation." (NRC, } 24 \\
\text { December 1993) }\end{array}$ & $\begin{array}{l}\text { Dike strengthening. } \\
\text { Politician: "The event emphasizes the } \\
\text { importance of dikes for the country" (political } \\
\text { discussion, } 9 \text { March 1994) }\end{array}$ & $\begin{array}{l}\text { Decreased delay through appeals because of } \\
\text { improved cooperation of different parties. } \\
\text { Minister: "Public participation and } \\
\text { consultation requires more time in initial phase, } \\
\text { but number of appeals decreased, which will } \\
\text { decrease delays. All parties need to work } \\
\text { together in a constructive manner." (political } \\
\text { discussions, } 9 \text { March 1994) }\end{array}$ \\
\hline $\begin{array}{l}\text { Spatial } \\
\text { e.g., Min }\end{array}$ & $\begin{array}{l}\text { ter of Infrastructure and Environment, scientists } \\
\text { Construction in floodplains, indirect blame of } \\
\text { provinces and municipalities. } \\
\text { Media: "The question remains who approved } \\
\text { all those developments in the low-lying areas? } \\
\text { Which authorities are responsible, and what } \\
\text { does it mean for the future?" (NRC, } 31 \\
\text { December 1993) }\end{array}$ & $\begin{array}{l}\text { media } \\
\text { Taking potential measures in spatial planning } \\
\text { sphere. } \\
\text { Scientist: "Damage can be reduced through } \\
\text { measures in the realm of spatial planning, e.g., } \\
\text { no construction in flood-prone areas, or only in } \\
\text { a manner that decreases damage, or adapting } \\
\text { existing buildings.' ( } A D, 4 \text { January } 1994)\end{array}$ & $\begin{array}{l}\text { Committee to develop measures to decrease } \\
\text { consequences of flooding. } \\
\text { Minister: "Awaiting the advice of the } \\
\text { committee, I expect a restraint on construction } \\
\text { in the floodplain." (political discussion, } 11 \text { May } \\
\text { 1994) }\end{array}$ \\
\hline
\end{tabular}

Eventually, in typical Dutch tradition, an advisory committee (Boertien II) was installed to study potential management measures (Warner 2008). The advice focused on river-widening and river-deepening measures, combined with nature restoration and gravel extraction. The advice was more in favor of these measures because environmental groups had already implemented such measures in the last decades along the Meuse demonstrating the advantage and feasibility of this approach (Van Heezik 2006). If these measures were not sufficient then embankments would be necessary (Commissie Boertien II 1994).

\section{Second shock event: flood of January 1995}

The second flood event, of January 1995, was a more prominent event affecting the rivers Meuse, Rhine, and Waal: 250,000 people had to be evacuated along the River Waal and 13,000 along the River Meuse. Afterward, it was remarked that the evacuation was not always necessary (Van Heezik 2006). This indicates the high shock effect of the event. According to Rosenthal (1988), the shock effect is increased when a society feels invulnerable to flooding, which was the case in the Netherlands, where major flooding had been prevented by extensive defense structures. Whereas in 1993 it was argued that the flooding was "not as bad as in 1953," the media aligned the event of 1995 with the storm surge of 1953. The event affected national policy (Rosenthal and 't Hart 1998, Driessen and De Gier 1999, Wiering and Driessen 2001). Table 5 summarizes the dominant frames: the "prostructural defense" frame opposed to the "ecosystem-based approach" and "prevention through spatial planning" frames. This created a high political pressure to act and opened a window of opportunity (Meijerink 2005).

Provincial politicians, hydro-engineers of governmental water authorities, and affected citizens quickly adopted a prodike strengthening frame that blamed the flood on the delay of dike strengthening caused by environmental protesters and bureaucratic procedures, e.g., EIA. Provincial politicians, e.g., Commissioner of the Queen in Gelderland, Jan Terlouw, lobbied actively for this frame at the national level, i.e., the Prime Minister. Hydraulic-engineers within Rijkswaterstaat were quick to develop a plan to strengthen embankments. They were in the right venue, i.e., the ministry, with enough credibility to lobby for this plan. Because of the political pressure for fast solutions, the Prime Minister promised to develop a Delta Plan and an Emergency Act to speed up decision making on dike enforcement. The use of the word "delta" functioned as frame bridging because it connected the frame to the prestigious Delta Committee that had developed a successful program after the disastrous storm surge of 1953 to secure the habitability of the country. The proponents of the frame highlighted values of safety during the crisis, which increased the resonance of the frame (frame amplification). The corresponding institutional consequences are summarized in Table 6. Several laws were indeed enacted to accelerate the strengthening of dikes: the Delta Plan Major Rivers (1995) that suspended EIA procedures and the long-term Flood Defense Act 
Table 5. Overview of frames identified after the flood of 1995 with representative quotations (1995-2014).

\begin{tabular}{|c|c|c|c|}
\hline Frames & Diagnostic & Prognostic & Motivational \\
\hline $\begin{array}{l}\text { Prostruct } \\
\text { e.g., gove }\end{array}$ & $\begin{array}{l}\text { nment officials (especially province and water boc } \\
\text { nelay of dike improvement due to lack of legal } \\
\text { strength, blaming of interest groups. } \\
\text { Provincial official: "The country is } \\
\text { ungovernable, because the individual interest is } \\
\text { put above the collective interest of security." } \\
(A D, 30 \text { January 1995) }\end{array}$ & $\begin{array}{l}\text { Strengthening dikes is priority, avoid delay. } \\
\text { Politician: "The need for dike reinforcement is } \\
\text { clear when you see such scenes on television." } \\
(N R C, 30 \text { January } 1995)\end{array}$ & $\begin{array}{l}\text { Accelerate dike raising through Emergency Act. } \\
\text { Minister "The need for emergency legislation to } \\
\text { facilitate and shorten the planning and } \\
\text { participation procedure is necessary." (political } \\
\text { discussions, } 4 \text { February 1995) }\end{array}$ \\
\hline $\begin{array}{l}\text { Ecosyste } \\
\text { e.g., Natu }\end{array}$ & $\begin{array}{l}\text {-based approach, } \\
\text { Human interference in hydrological processes, } \\
\text { e.g., channelization or dikes, or meteorological } \\
\text { processes, e.g., climate change. } \\
\text { Nature organization: "In recent centuries, the } \\
\text { technocrats have restrained the river. The } \\
\text { calamities of today are a result of a too far- } \\
\text { reaching desire to dominate." (NRC, } 2 \\
\text { February 1995) }\end{array}$ & $\begin{array}{l}\text { Sustainable flood risk management, finding } \\
\text { more ecosystem-based solutions to give room } \\
\text { to the river. } \\
\text { National water manager: "The river system } \\
\text { should have a more natural character. Rain } \\
\text { must infiltrate the soil, so water comes } \\
\text { gradually into the river. Moreover, the river } \\
\text { should have more room to keep the damage } \\
\text { from high water within limits." (NRC, } 31 \\
\text { October 1996) }\end{array}$ & $\begin{array}{l}\text { Stimulate river widening measures. } \\
\text { Politician: "The cabinet had asked for an } \\
\text { adaptation of the normative water level, to } \\
\text { avoid new dike strengthening after } 2000 \text {, the } \\
\text { Minister did not agree, because she thinks the } \\
\text { solution needs to be found in river widening } \\
\text { measures." (political discussion, } 13 \text { November } \\
\text { 1996) }\end{array}$ \\
\hline $\begin{array}{l}\text { Preventic } \\
\text { e.g., Scie }\end{array}$ & $\begin{array}{l}\text { through spatial planning } \\
\text { tists, international, water managers } \\
\text { Spatial planning in floodplains increased } \\
\text { vulnerability and decreased retention capacity } \\
\text { of soil. } \\
\text { Scientists: "The flooding in the Meuse is the } \\
\text { consequence of shortcomings in planning: } \\
\text { building in the floodplain." ( } A D, 25 \text { February } \\
\text { 1995) }\end{array}$ & $\begin{array}{l}\text { Stop increase of vulnerable areas through } \\
\text { urbanization. } \\
\text { EU politician: "They argue that further } \\
\text { urbanization in vulnerable areas along these } \\
\text { rivers needs to stop. A construction ban needs } \\
\text { to be considered." ( } A D, 6 \text { February 1995) }\end{array}$ & $\begin{array}{l}\text { Restrict construction in floodplain. } \\
\text { Minister: "Activities that are necessary (bridges } \\
\text { etc.) are still allowed if they fulfil certain } \\
\text { preconditions. Houses should not be built } \\
\text { anyway, if it can be avoided." (Trouw, } 19 \\
\text { December 1996) }\end{array}$ \\
\hline
\end{tabular}

(1996) that included the consideration of LNC-values, showing the influence of the environmental groups. In conclusion, the existing flood defense approach was further formalized.

However, the media analysis showed that the support for dike strengthening decreased again after the first shock waves and first legal and practical responses. In the last decades preceding the shock events, the environmental coalition was very active. For example, Ed Nijpels, the chair of World Wide Fund, had actively lobbied for the integration of water and nature (Huitema and Meijerink 2009). Because of the critique on the engineering approach of Rijkswaterstaat with its negative environmental and cultural consequences, other professions besides engineers had entered the organization to facilitate the integration of water and nature. Biologists like Henk Saijs, or green engineers like Wim Silva and Pieter Huisman received important functions within Rijkswaterstaat, so that next to the hydraulic-engineering community an ecological strand also developed. Close cooperation between hydraulic-engineers and ecologists developed (Roth et al. 2006). After the flood, this environmental coalition dared to question whether the traditional defense approach was fit for the future or if it would only increase risks by modifying natural process and creating a false sense of security, which would demand continuous dike strengthening. Inspired by Plan Stork, nature organizations, e.g., Frans Vera of Staatsbosbeheer, developed radical environmental visions of river corridors (see Staatsbosbeheer 2003; frame: ecosystem-based approach). The legitimacy of these questions and thereby the resonance of this frame was increased because the two flood events were not seen as isolated incidents but conceived to be potentially part of a larger trend: climate change (frame extension), which demanded new management approaches because the dike could not be strengthened forever (frame transformation). Coincidently, the Dutch meteorological institute (KNMI) had just published climate change projections in 1995 supporting the credibility of this concern (Roth et al. 2006). The resonance of the frame was also increased because it aligned with international developments. On the international level politicians and scientists stressed that urbanization and the resulting increased damage potential had contributed to the severity of the event asking for a more integral management approach (frame: prevention through spatial planning). This aligned with and increased the credibility of the ecosystem-based frame (cf. Huitema and Meijerink 2009). Both frames were supported by minister Jorritsma (Transport and Water) and De Boer (Housing, Spatial Planning and Environment). The ministers supported the frames because they aligned with a broader discourse on sustainability (frame bridging), which was supported by the society and the liberal-social democratic government, thus offering a discursive opportunity structure. Eventually, Rijkswaterstaat was tasked by the minister to explore the possibilities for river-widening projects.

The corresponding institutional consequences of the frames are summarized in Table 6 . The policy guideline Room for the River corresponds with the prevention through spatial planning frame, 
because it prohibits construction in the floodplain. The major policy project Room for the River, a project with substantial financial budgets and new cooperation agreements between different governmental actors, corresponds to the ecosystembased approach frame. Room for the River reflects a compromise. Even though, the shift is described as fundamental "the emphasis shifts from dike improvement to river-widening. Dike improvement would only be used when other measures are not feasible or cannot be financed" (PKB 2006:7), the ideas are less radical than foreseen by the environmental coalition. Fulfilling safety standards by controlling the water and keeping it away from people with hydro-engineering measures is still at the core of the policy. Despite the advocacy work of the environmental coalition, the need to fulfill stringent safety regulations gave power positions to hydro-engineers. This indicates that the policy changes are influenced by the interaction of agency and structure.

Table 6. Institutional consequences after the flood of 1995.

\begin{tabular}{|c|c|c|}
\hline $\begin{array}{l}\text { Dimensions } \\
\text { PAA }\end{array}$ & First response & Second response \\
\hline Discourses & $\begin{array}{l}\text { Hydro-technocratic } \\
\text { discourse (frame: } \\
\text { accelerated dike } \\
\text { strengthening) }\end{array}$ & $\begin{array}{l}\text { Integrated water resource } \\
\text { management } \\
\text { (frame: prevention through spatial } \\
\text { planning, and ecosystem-based } \\
\text { approach) }\end{array}$ \\
\hline Rules & $\begin{array}{l}\text { Delta Plan Great Rivers } \\
\text { Emergency Act Great } \\
\text { Rivers } \\
\text { Flood Protection Act }\end{array}$ & $\begin{array}{l}\text { Policy guideline Room for the } \\
\text { River } \\
\text { Project Room for the River } \\
\text { (because the policy guideline itself } \\
\text { is not an instrument to implement } \\
\text { measures) }\end{array}$ \\
\hline Actors & $\begin{array}{l}\text { No major changes in } \\
\text { responsibilities }\end{array}$ & $\begin{array}{l}\text { Increased importance of } \\
\text { decentralized authorities. } \\
\text { Integration with spatial planning } \\
\text { was increased }\end{array}$ \\
\hline Resources & $\begin{array}{l}\text { National government } \\
\text { contributes to the dike } \\
\text { strengthening measures }\end{array}$ & $\begin{array}{l}€ 2.3 \text { billion from } 2006-2015 \text { and } \\
\text { investment by regions in spatial } \\
\text { quality }\end{array}$ \\
\hline
\end{tabular}

Persistence of policy consequences

The media analysis revealed that over the years the initial awareness of flood risks due to the shock event declined and the pressure by municipalities and provinces to grow economically became stronger. According to Kingdon (1995), the policy window had closed and the political stream started to prioritize other issues. So, the successor to the policy guideline Room for the River, which is called the Policy Guideline Major Rivers, is less restrictive and offers once again more possibilities to build in the floodplain (V\&W and VROM 2006). Thus, the slight shift toward a prevention strategy was weakened.

Additionally, the societal and political discursive opportunity structure changed again at the beginning of the 21 st century because of political changes toward a center right government. This government reduced the financial means available for nature development, thus the support for ecosystem-based solutions started to decline. Because of the economic crisis, efficiency gained in importance, which increased the support for structural defense measures. A national water manager summed it up: "In 1995, we chose to give more room to the river. But that does not seem to be enough, the Netherlands just need dikes" (Trouw, 16
September 2014). Although river widening measures are still mentioned in the Delta Program in 2014 (a climate adaptation program that developed a vision for Dutch FRM for future decades), $€ 8$ billion are to be invested in dike strengthening from 2015 to 2028 , while only $€ 200$ million are reserved for river widening (I\&M and EZ 2014). Civil servants evaluated this amount as sufficient, whereas nature organizations were more critical (Klimaatbuffers 2015). To sum up, the shift toward an ecosystem-based defense approach lost support in the long term and the structural defense approach restrengthened its dominance because it had been strongly institutionalized.

\section{Poland}

For most of its history water and FRM in Poland have been dominated by a hydro-technical approach characterized by dikes, drainage, and reservoirs. During the Communist era, efficiency and environmental values were less important when deciding on investments; hydrological expertise was the key and was institutionally embedded (Majewski 2011). Since the 1980s water and FRM have been losing political and financial support. After the Iron Curtain fell and the systematic transformation after $1989 / 1990$ was underway, a different administrative context was established. During this time, other aspects like water quality got more attention than FRM. As a result, technical expertise and financial support for FRM declined (Kindler et al. 2014, Matczak et al. 2016). Table 7 summarizes the main characteristics of the Polish FRGA. However, the hydro-technical approach is less institutionalized and more fragmented than in the Netherlands.

Table 7. Characteristics of the Polish flood risk governance arrangement (FRGA) before the flood event of 1997.

\begin{tabular}{|c|c|}
\hline $\begin{array}{l}\text { Characteristics of the } \\
\text { FRGA }\end{array}$ & Poland \\
\hline $\begin{array}{l}\text { Discourse } \\
\text { (hegemonic) }\end{array}$ & $\begin{array}{l}\text { Hydro-technical discourse (engineering measures } \\
\text { offer protection) }\end{array}$ \\
\hline Rules & $\begin{array}{l}\text { Fragmented legislation } \\
\text { No legal safety standards }\end{array}$ \\
\hline Actors & $\begin{array}{l}\text { National, provincial, and regional water managers, } \\
\text { i.e., fragmentation of competencies } \\
\text { Since } 1990 \text { a decrease in well-trained engineers }\end{array}$ \\
\hline Power/Resources & $\begin{array}{l}\text { Water managers dependent on national resources, } \\
\text { limited availability of financial resources }\end{array}$ \\
\hline
\end{tabular}

First shock event: flood of 1997

The flood of July 1997 inundated about 2\% of Polish territory and caused losses of around $€ 3$ billion and 55 fatalities (Choryński et al. 2012). The severe consequences were the result of record water levels and inappropriate management infrastructure. The event was immediately labeled "the flood of the Millennium," which emphasizes its function as a shock event. It increased the interest of politicians and the media in flood risks. Table 8 summarizes the dominant frames: prostructural defense, crisis management, and decentralization.

National politicians, including the Polish Prime Minister Włodzimierz Cimoszewicz and other members of parliament adopted the prostructural defense frame, which was, as a result, the most dominantly represented in political documents. Members of Parliament (MPs) shared the idea that hydrotechnical measures have the capacity to effectively stop future 
Table 8. Overview of frames identified after the flood of 1997 with representative quotations. FRM = flood risk management.

\begin{tabular}{|c|c|c|c|}
\hline Frames & Diagnostic & Prognostic & Motivational \\
\hline \multicolumn{4}{|c|}{$\begin{array}{l}\text { Prostructural defense, } \\
\text { e.g., Politicians, media }\end{array}$} \\
\hline & $\begin{array}{l}\text { Lack of flood infrastructure. } \\
\text { Minister: "I take full responsibility for these } \\
\text { words: it was impossible to deal with such a } \\
\text { flood. The only thing possible was to minimize } \\
\text { flood losses." ( } G W, 17 \text { July } 1997)\end{array}$ & $\begin{array}{l}\text { Hydro-technical solutions can minimize flood } \\
\text { risk effectively. } \\
\text { Prime Minister: "Despite too few water } \\
\text { reservoirs, the existing reservoirs passed their } \\
\text { test. Thus, it is the question not "how" but } \\
\text { "when" we should build additional reservoirs in } \\
\text { the future." (political discussion, 16 July 1997) }\end{array}$ & $\begin{array}{l}\text { Increasing availability of financial means. } \\
\text { Politician: "It is obvious that financial } \\
\text { resources dedicated to Water Management } \\
\text { Boards, responsible for maintenance and } \\
\text { reconstruction of dikes, are too low and should } \\
\text { be increased." (political documents, } 30 \\
\text { September 1998) }\end{array}$ \\
\hline \multicolumn{4}{|c|}{$\begin{array}{l}\text { Crisis management, } \\
\text { e.g., Politicians, media }\end{array}$} \\
\hline o & $\begin{array}{l}\text { Ad hoc crisis management (rescue and recovery } \\
\text { actions) with insufficient technological and } \\
\text { financial capacities to deal with crises } \\
\text { effectively. } \\
\text { Minister: "We have no crisis management } \\
\text { coordination center, a lack of digital data } \\
\text { support, computers and undeveloped } \\
\text { infrastructure, to effectively communicate risks } \\
\text { to society." }(G W, 17 \text { July } 1997)\end{array}$ & $\begin{array}{l}\text { Complementary crisis management system } \\
\text { needs to be established. } \\
\text { Politician: "From the government side it is } \\
\text { complementary crisis management action that } \\
\text { was lacking during the flood." ( } G W, 5 \text { August } \\
\text { 1997) }\end{array}$ & $\begin{array}{l}\text { Establishment of crisis management } \\
\text { institutions (including legislation and funding). } \\
\text { Scientist: "Before the flood we had started to } \\
\text { build emergency and warning infrastructure } \\
\text { and meanwhile the flood occurred } \\
\text { unexpectedly. Fire Brigades have been funded } \\
\text { even before the flood and they passed the test. } \\
\text { Now it is time to invest in these structures more } \\
\text { rapidly." ( } G W, 20 \text { August 1997) }\end{array}$ \\
\hline \multicolumn{4}{|c|}{$\begin{array}{l}\text { Decentralization. } \\
\text { e.g., Politicians, media, citizens }\end{array}$} \\
\hline & $\begin{array}{l}\text { State unveiled ineffectiveness in dealing with } \\
\text { high water flows. } \\
\text { Media: "Policemen, soldiers, even priests can } \\
\text { fail but the State cannot. However, in fact, the } \\
\text { State failed entirely." ( } G W, 26 \text { July 1997) }\end{array}$ & $\begin{array}{l}\text { Local and regional level of administration } \\
\text { should be established and more included in } \\
\text { FRM. } \\
\text { Politician: "Flood of } 1997 \text { unveiled the role of } \\
\text { local and regional government. This event } \\
\text { definitely provided arguments for a need for } \\
\text { decentralization processes that have to be } \\
\text { done." (political document, 16 July 1997) }\end{array}$ & $\begin{array}{l}\text { Decentralization process of FRM. } \\
\text { Politician: "The ruling coalition had } 4 \text { years } \\
\text { and all the proper instruments to introduce } \\
\text { administrative reform. The only reason why } \\
\text { they did not do this were vested interests - in } \\
\text { order to sustain the political coalition." ( } G W, 8 \\
\text { September 1997) }\end{array}$ \\
\hline
\end{tabular}

flood losses and even more skeptical politicians (e.g., Zbigniew Sobotka, vice-minister of Internal Affairs), admitted that flood defense infrastructure can be quite effective in minimizing flood losses. The resonance of this frame was high because it was amplified by the already dominant hydro-technocratic discourse, so that technical solutions were instantly seen as the best solution. The previous shortcomings of these measures were mainly attributed to the lack of availability of financial means, while the shortcomings in the institutional organization of defense management were barely discussed. As a consequence more financial means were temporarily made available for flood infrastructure (see Table 9).

In the crisis management frame, politicians and the media blamed the state and its administrative structures for the high number of fatalities because they were seen as ineffective in providing appropriate flood warnings and organizing appropriate crisis management. This frame was supported both by politicians (e.g., Krzysztof Janik, Under-secretary of State for self-government affairs) and by influential hydrotechnical experts (e.g., Prof. Janusz Zalewski, head of the national Programme for the River Odra - 2006 that was developed after the flood of 1997). The resonance of this frame was amplified for two reasons. First, its importance was enhanced by the media that focused on the tragedies of the citizens, who also blamed the state. Second, its resonance was increased because proponents, such as the influential self-government experts Prof. Michał Kulesza and politician Hanna Suchocka (former Prime Minister), bridged the
Table 9. Institutional consequences after the flood of 1997. PAA = policy arrangement approach.

\begin{tabular}{|c|c|c|}
\hline $\begin{array}{l}\text { Dimensions } \\
\text { PAA }\end{array}$ & First response & Second response \\
\hline Discourses & $\begin{array}{l}\text { Prodike strengthening: } \\
\text { hydro-technocratic } \\
\text { discourse remained } \\
\text { dominant }\end{array}$ & $\begin{array}{l}\text { Crisis management to mitigate } \\
\text { flooding }\end{array}$ \\
\hline Rules & $\begin{array}{l}\text { New programs to } \\
\text { implement structural } \\
\text { measures (ad hoc) }\end{array}$ & $\begin{array}{l}\text { Act on Crisis Management } 2007 \\
\text { (direct) } \\
\text { Act on Natural Disaster } 2002 \\
\text { (direct) } \\
\text { Administration reform } 1999 \\
\text { (indirect) }\end{array}$ \\
\hline Actors & No change & $\begin{array}{l}\text { More competences for } \\
\text { decentralized actors (state fire } \\
\text { brigades, local government units) }\end{array}$ \\
\hline Resources & $\begin{array}{l}\text { Increase in outlays of } \\
\text { fixed assets (both from } \\
\text { state budget and World } \\
\text { Bank) }\end{array}$ & $\begin{array}{l}\text { Increase in state fire brigades } \\
\text { budget }\end{array}$ \\
\hline
\end{tabular}

crisis management frame to the general discourse of decentralization. This widely spread discourse criticized that not enough power and responsibilities were given to the local and regional governments after the end of the Communist era. Additionally, decentralization of some sectors, e.g., crisis 
Table 10. Overview of frames identified after the flood of 2010 with representative quotations.

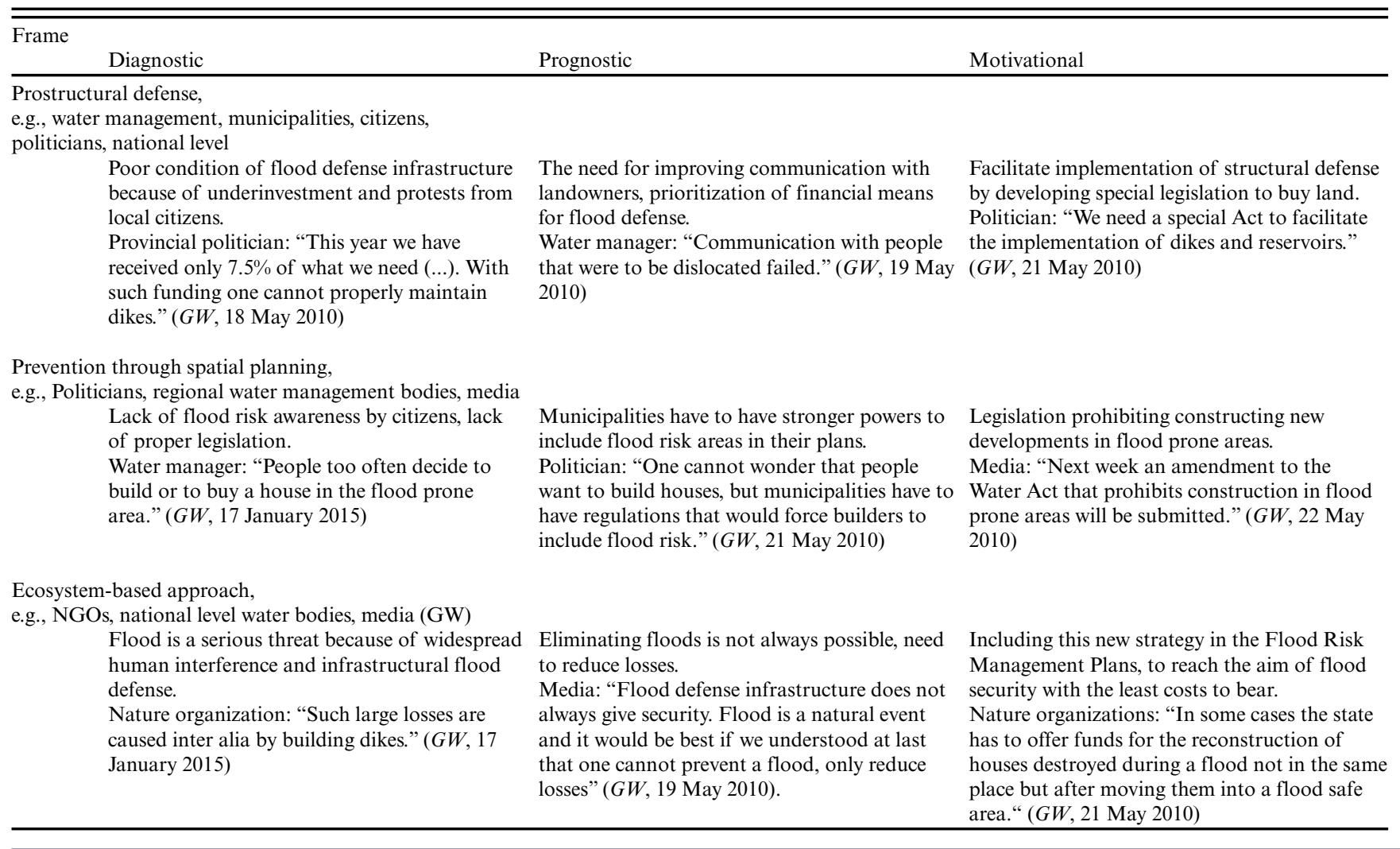

management, had already been discussed in 1992 after a significant fire accident. Back then, actions had been taken to enhance the operational capacities of the state fire brigades. However, the flood event of 1997 emphasized shortcomings and delays, thereby reviving the idea of administrative reform. As a consequence, crisis management was reformed and further institutionalized, affecting all dimensions of the PAA (see Table 9).

\section{Second shock event: flood of 2010}

Even though the next major flood, that of 2010, brought similar losses of about $€ 3$ billion, it was not considered as serious an event as the one in 1997, partly because it caused fewer fatalities. After 1997, the organization of crisis response was improved, so that there was more space for other arguments to be raised. Furthermore, additional actor coalitions have been given a voice in the framing contest; environmental NGOs that were not present in the discussions following the flood of 1997 have now become active. Newspaper articles referring to the shock event of 2010 were mostly concentrated on three frames: prodike strengthening; improvement of spatial planning; and ecosystem-based management approaches (Table 10).

Members of Parliament and water managers adopted, again, the prodike strengthening frame. They blamed the poor condition of the dikes, and asked for increased investment in structural defense measures and new legislation. Although after the flood of 1997 large programs in this sphere were launched, e.g., Program for the River Odra 2006, they still suffered from poor coordination and underinvestment. There was a conflict of interests between public water managers, i.e., Regional Water Management Boards, that planned to build certain structures and local communities that did not agree that they had to leave their houses. This caused delay, especially in Racibórz, Wielowieś Klasztorna or Świnna Poręba. High executive politicians, e.g., Bronisław Komorowski, Marshall of Sejm, proposed changes in legislation that would enable water managers to expropriate land. The new legislation was introduced at short notice. The resonance of the frame was high because the flood coincided with the presidential elections. Politicians wanted to present solutions, and hydro-technical measures were still the solution that was the most taken for granted. The institutional consequences were directly related to an increased availability of financial means (Table 11).

Representatives of Regional Water Management Boards emphasized the problem of risk awareness and blamed the citizens for building in flood-prone areas (spatial planning frame). They proposed measures to prevent the occupation of flood-prone areas. The resonance of the frame was increased because it was extended to a general problem of the whole spatial planning system. The spatial planning system was criticized as ineffective, mainly because of the weak position of municipalities. As an institutional consequence, the Water Act was amended with intensive support from politicians. Municipalities became obliged to take flood risk into consideration, which did not always align with their financial interest to expand economically (Table 11). 
Table 11. Institutional consequences after the flood of 2010. PAA = policy arrangement approach.

\begin{tabular}{lll}
\hline \hline $\begin{array}{l}\text { Dimensions } \\
\text { PAA }\end{array}$ & First response & Second response \\
\hline Discourses & $\begin{array}{l}\text { Hydro-technical } \\
\text { discourse still } \\
\text { dominant }\end{array}$ & $\begin{array}{l}\text { Ecosystem-based solutions gained } \\
\text { attention, in connection with spatial } \\
\text { planning, which also gained in } \\
\text { importance and acceptance }\end{array}$ \\
Rules & $\begin{array}{l}\text { Right to } \\
\text { expropriate } \\
\text { No change }\end{array}$ & $\begin{array}{l}\text { consider flood risk in spatial plans } \\
\text { Increased cooperation but also } \\
\text { conflict between water managers and } \\
\text { environmentalists } \\
\text { Ad hoc investments in eco- } \\
\text { infrastructural projects }\end{array}$ \\
& Increased budget &
\end{tabular}

NGOs, in particular the World Wide Fund, adopted the ecosystem-based approach frame. They stressed the negative influences of human activity on nature, e.g., through building dikes. They argued that dikes should be relocated or demolished to give more space to the rivers and let them return to their natural state. The resonance of the frame was relatively high because it could be bridged to the proenvironmental discourse that was supported by the EU, which Poland joined in 2004. The frame should have been implemented through spatial planning by identifying future flood risk zones. However, a broad scheme was lacking and projects were implemented ad hoc; this was made worse by increased antagonism between environmental NGOs and traditional water managers. One successful project was an NGO proposal that could be realized in cooperation with water administration bodies (Domaszków-Tarchalice polder). However, this was rather an exception; often there are conflicts that delay the management process.

\section{Persistence of policy consequences}

The changes in crisis management that succeeded the flood of 1997 persisted. Crisis management was reformed, which led to permanently institutionalized structures, e.g., the Act on Crisis Management 2007, with sufficient funding, political support, and effective response activities, i.e., a shift toward the preparation strategy. The defense strategy was strengthened by receiving more financial investments. However, the organization of the strategy remained unchanged, in terms of the actors involved in FRM, the central mode of financing, and the influential role of politicians. After the shock wave declined, so did the political commitment to financially invest in the defence strategy; as a result, the infrastructure was only marginally improved. The defense strategy was neither permanently strengthened nor institutionally reformed.

The flood of 2010 had less policy effect than the flood of 1997 , partially because of the lower number of fatalities (16 people; Choryński et al. 2012). Contrary to the crisis management frame of 1997, which was bridged to an administrative reform of decentralization, the spatial planning and ecosystem-based approach of 2010 have not brought change into prioritizing economic development. At the moment, we cannot make any statements about long-term consequences; however, adjustments to spatial planning and the trend toward a more proenvironmental approach are still ongoing, but slowly.

\section{DISCUSSION}

Previously, we explained that there are a number of similarities between both countries, for example, regarding flood defense as a dominant strategy, hydro-engineering expertise, and the dominant role of state involvement. Differences are to be found in the level of resource availability and the way people look at FRM in the Netherlands and in Poland. Consequently, the framing of flood events differs (Table 12). We compare how the shock events were received and framed by different actors, and consider what can be said about corresponding policy change in the long run.

Table 12. Main points of comparison between the Netherlands and Poland. FRGA = flood risk governance arrangement.

\begin{tabular}{|c|c|}
\hline The Netherlands & Poland \\
\hline \multicolumn{2}{|l|}{ FRGA before the flood event } \\
\hline $\begin{array}{l}\text { Structural defense approach: } \\
\text { institutionalization = evolved }\end{array}$ & $\begin{array}{l}\text { Structural defense approach: } \\
\text { institutionalization = fragmented }\end{array}$ \\
\hline \multicolumn{2}{|l|}{ Dominant frames 1 st event } \\
\hline Additional study & Prostructural measures \\
\hline prostructural measures & Crisis management \\
\hline Spatial planning shortcoming & Decentralization \\
\hline \multicolumn{2}{|l|}{ Dominant frames 2 nd event } \\
\hline \multicolumn{2}{|l|}{ Prostructural measures } \\
\hline \multicolumn{2}{|c|}{ Prevention through spatial planning } \\
\hline \multicolumn{2}{|l|}{ Ecosystem-based approach } \\
\hline \multicolumn{2}{|l|}{ Institutional consequences } \\
\hline $\begin{array}{l}\text { Procedural streamlining of } \\
\text { structural defense approach } \\
(1995)\end{array}$ & $\begin{array}{l}\text { Temporary financial support of } \\
\text { flood defense }(1997,2010)\end{array}$ \\
\hline $\begin{array}{l}\text { Temporary adjustment of } \\
\text { defense approach (ecosystem- } \\
\text { based; 1995) }\end{array}$ & $\begin{array}{l}\text { Persistent shift toward flood } \\
\text { preparation strategy (1997) }\end{array}$ \\
\hline $\begin{array}{l}\text { Minimal (and temporary) shift } \\
\text { toward flood prevention } \\
\text { strategy (1995) }\end{array}$ & \\
\hline
\end{tabular}

First, the flood events have a different societal impact. In the Netherlands, the reactions to the event of 1993 were limited in comparison with the reactions to the second event. It was the occurrence of two consecutive floods with potentially disastrous consequences that brought into focus the vulnerability of the country, especially in light of climate change. As Rosenthal (1988) explains, the effect was increased because Dutch citizens normally feel invulnerable because of the high protection standards. In Poland, on the other hand, the flood of 1997 created bigger shock waves than in 2010, because of the less organized evacuation action taken during the flood and a higher number of fatalities. Second, in Poland, the wider public blamed above all the government for the lack of structural measures, whereas, in the Netherlands, the environmental interest groups were blamed for delaying structural dike strengthening, and to a lesser degree spatial planning authorities were also considered to be culpable. Third, the corresponding institutional consequences show similarities, as well as differences, depending on the shock wave and the time that has passed after the event. In both countries, we see that shock events can increase the political and societal awareness of flood risk and its management (window of opportunity). As a result, shock events increase the receptiveness for different frames among a broader set of actors, which can lead to different institutional effects. In both countries, the immediate 
reaction was to strengthen flood defense in the Netherlands by streamlining the procedure and in Poland by providing more financial resources. That indicates that in the short term the shock event caused actually a strengthening of the trusted defense approach, which aligns with findings of previous research (Driessen and De Gier 1999). From a framing perspective, one explanation may be that actors who support the existing approach can quickly develop and disseminate their frame because of their established expert position that gives them access to media and political circles. Furthermore, the existing approach offers a familiar reference system for politicians and citizens, so that the wider public understands it and feels comforted by the immediate action; particularly in the Netherlands flood safety can be seen as an important overarching public interest.

Our findings suggest that frames that deviate from the traditional management approach need longer to develop and to spread in the right circles. Therefore, they seem more likely to generate midterm policy responses. In the Netherlands, those midterm policy responses have consisted of an adjustment of the defense strategy toward a more ecosystem-based approach and to a lesser degree an increased consideration of spatial planning in terms of prevention mainly to support the ecosystem-based approach, confirming earlier research (Van der Brugge et al. 2005, Huitema and Meijerink 2007). In Poland, we see a clear broadening of strategies toward preparation and response. How can those differences be explained? On the one hand, the discourse opportunity structure differed, which increased the resonance of different frames. On the other hand, in the Netherlands the defense approach was highly institutionalized and stabilized. Additionally, the existing organizational structures were hardly challenged because the defense approach successfully prevented a more severe catastrophe: the dikes held. That legitimized flood defense and the idea of controlling water, which is still the underlying notion of the ecosystem-based approach. It led to a compromise of the two opposing frames. Whereas in Poland the defense approach was less institutionalized and its organizational structures were challenged, because it was not successful: dikes had breached, people had died. Flood defense lost legitimacy and a new strategy, in line with the discursive opportunity structure, was developed with the aim of preventing fatalities, not completely substituting but compensating the shortcomings of the defense approach. This strategy was relatively effective during the 2010 flood event so that the shock wave of the event was limited. Nevertheless, ideas of an ecosystem-based approach had become popular in Poland in 2010. A reason could be the accession of Poland to the EU in 2004. The Water Framework Directive (2000) supports ecosystem-based ideas. That suggests that EU directives could create discourse opportunity structures. The ecosystem-based approach is in the developmental phase, but not yet institutionalized, because it has been difficult for engineers and environmentalists to reach consensus and share resources.

How persistent is the policy change? Once the shock waves have subsided, the windows of opportunity have closed, and the discursive opportunity structures have changed, the financial and political commitment is often reduced, because the political stream focuses on other priorities again. We see this in Poland with flood defense, which lost financial priority once the shock waves decreased and other fields needed financial investment. In contrast, the strategy of preparation, which needs less financial investment and is additionally supported by local citizens and governments, is permanently institutionalized and until now it has remained uncontested. In the Netherlands as well, financial support for the ecosystem-based approach has been reduced. It also lost political support because of a shift to a more conservative government, i.e., changes in the discourse opportunity structure. In the meantime, however, the structural flood defense approach was still highly institutionalized, which means it had remained stable and technical water managers had preserved its influence and power. As the discursive opportunity structure had changed, which was supported by the economic crisis, the technical water managers could again advance the popularity of the more costefficient structural defense approach. These observations imply that long-term institutional change is dependent on resource availability, and the prioritization of resource allocation, and also on the evolution and degree of institutionalization of the initial management approach.

Interpretative studies are normally characterized by a high degree of internal validity. We analyzed the endogenous processes in a comprehensive way taking many explanatory factors into consideration. In our research, these factors need to be reported in the media or the policy documents; however, there is always a chance that unreported explanatory factors were also influential, or factors that were not connected to the shock event. Therefore, we can only identify corresponding institutional dynamics, not causal relationships.

We acknowledge that the scope of our analysis is limited. We focused on dominant, national frames and formal institutional changes; that means that frames of a regional scope or frames that caused informal change were not considered. Furthermore, it is likely that not all frames are presented in the media; there might even be an intentional bias that only some frames are reported. We tried to counteract this by choosing newspapers of different political orientations. Therefore, we think that our approach is appropriate in relation to our initial aim, i.e., to analyze endogenous institutional processes.

\section{CONCLUSION}

What are the further insights on the relationship between shock events and the initiated institutional dynamics on increasing societal resilience? In the case of the Netherlands and the events of 1993 and 1995, the first response was to "recover and return" by slightly adjusting existing procedures. In terms of resilience that increased the capacity to resist. Even though financial support for the ecosystem-based approach decreased after a while, the involvement of a wider set of actors and the slow increase of awareness for flood issues as well as environmental values remained and is generally seen as beneficial for resilience (Van Herk et al. 2015).

In Poland, the shock event of 1997 put the flood problem on the political agenda. It showed the shortcomings of the existing defense approach, i.e., the lack of systematic financing, and triggered the development of emergency management, which reduced the fatalities in the flood of 2010, at least to some extent. It increased resilience, i.e., the ability to absorb and recover. However, the shock event did not cause fundamental improvements to the structural defense strategy, but only additional short-term financial investment. River-widening measures have been discussed since the flood of 2010; however, at the moment their implementation is rather ad hoc. Discussions between environmentalists and water engineers sometimes inhibit 
the effective implementation of projects and, therefore, might even slightly hamper resilience.

Our research suggests that shock events, such as floods, show the shortcomings of FRGAs by bringing the risk into focus. They open up institutional arrangements and make them more susceptible to change. Shock events test the capacity to resist and bounce back, thus giving opportunities for adapting and learning. The research suggests that the direction of change accelerated by a shock event is dependent on the actors and the frames they introduce, and their ability to increase the resonance of the frame. This resonance can be increased (and decreased) by the discursive opportunity structure and the existing FRGA that stabilizes certain legislation and the power position of actors. Furthermore, the permanence of change seems to be especially influenced by the availability of resources, or the willingness to allocate resources, as well as the evolution of the existing FRGA.

Hence, it can be assumed that a shock event can facilitate a shift toward different forms of resilience. A shock event can increase resilience by either accelerating a diversification of strategies (see Poland) or an adaptation of the dominant existing strategy (see the Netherlands). In Poland the flood events have led to increased attention for strengthening the strategies that are connected to "absorb and recover" whereas in The Netherlands it has mostly led to increased investments in the "capacity to resist," in terms of resilience of the engineering-based infrastructural system. Although there is political awareness of the need to bring back historical societal resilience in terms of resilience of citizens and communities, this is hardly translated in changes of resources for flood risk strategies in the direction of "absorb and recover," e.g., the flood risk awareness among citizens remains low (OECD 2014). Thus, peoples' resilience is not reintroduced. Furthermore, resilience might also be hampered if conflicting frames fail to achieve a resolution, as is partly the case in Poland with the struggle between environmental organizations and water managers. Shock events open up the possibility to increase resilience, but it is dependent on the context as to how far resilience is increased.

Our analysis allowed us to estimate and analyze the resonance of frames, by providing information about alignment strategies and discursive opportunity structures. For the Polish case, the research seems to have generated some new insights because little research was previously being conducted. However, for the Dutch case as well, we could extend existing research (e.g., Driessen and De Gier 1999, Van der Brugge et al. 2005, Huitema and Meijerink 2007, Van Herk et al. 2015) by refining the interrelation between shock events, framing, and institutional change through an analysis of the endogenous processes. We analyzed why some frames generate institutional stability or change and subsequently why this change was more permanent or not. These insights are not automatically generalizable to other contexts, but it is likely that similar processes play a role and influence the effects of frames. Further research would be necessary to test this and to analyze the effect on an even longer time frame.

\section{Responses to this article can be read online at:} http://www.ecologyandsociety.org/issues/responses. $\mathrm{php} / 8764$

\section{Acknowledgments:}

This paper has been written in the framework of the EU FP7 project $S T A R F L O O D$. This research has received funding from the European Commission under grant agreement no. 308364. As part of this study, we would like to thank our commissioners and the flood risk management professionals who participated in this research, for their time and insight.

\section{LITERATURE CITED}

Alfieri, L., P. Burek, L. Feyen, and G. Forzieri. 2015. Global warming increases the frequency of river floods in Europe. Hydrology and Earth System Sciences 19(5):2247-2260. http://dx. doi.org/10.5194/hess-19-2247-2015

Baumgartner, F., and B. D. Jones. 1993. Agenda and instability in American politics. University of Chicago Press, Chicago, Illinois, USA.

Benford, R. D., and D. A. Snow. 2000. Framing processes and social movements: an overview and assessment. Annual Review of Sociology 26:611-639. http://dx.doi.org/10.1146/annurev.soc.26.1.611

Birkland, T. A. 1998. Focusing events, mobilization, and agenda setting. Journal of Public Policy 18(1):53-74. http://dx.doi. org/10.1017/S0143814X98000038

Blowers, A., and P. Leroy. 2003. Environment and society: shaping the future. Pages 255-283 in A. Blowers and P. Glasbergen, editors. Environmental Policy in an International Context. Volume 3. Elsevier, Oxford, UK. http://dx.doi.org/10.1016/s1874-7043(03) 80029-X

Boin, A., P. 't Hart, and A. McConnell. 2009. Crisis exploitation: political and policy impacts of framing contests. Journal of European Public Policy 16(1):81-106. http://dx.doi. org/10.1080/13501760802453221

Boonstra, F. 2004. Laveren tussen regio's en regels: verankering van beleidsarrangementen rond plattelandsontwikkeling in Noordwest Friesdland, de Graafschao en Zuidwest Salland. Koniglijke Van Gorcum, Assen, The Netherlands.

Chaffin, B. C., H. Gosnell, and B. A. Cosens. 2014. A decade of adaptive governance scholarship: synthesis and future directions. Ecology and Society 19(3):56. http://dx.doi.org/10.5751/ ES-06824-190356

Choryński, A., I. Pińskwar, W. Kron, G. R. Brakenridge, and Z. W. Kundzewicz. 2012. Catalogue of large floods in Europe in the 20th century. Pages 27-54 in Z. W. Kundzewicz, editor. Changes in flood risk in Europe. CRC, Boca Raton, Florida, USA. http:// dx.doi.org/10.1201/b12348-5

Commissie Boertien I. 1993. Toetsing uitgangspunten rivierdijksversterkingen. Rijkswaterstaat, 's-Gravenhage, The Netherlands. [online] URL: http://repository.tudelft.nl/view/ hydro/uuid\%3A983a552f-68f3-4a04-934f-24cb54200a6e/

Commissie Boertien II. 1994. Onderzoek waternood Maas: De Maas Meester. Rijkswaterstaat, Delft, The Netherlands. [online] URL: http://publicaties.minienm.nl/documenten/onderzoek-watersnoodmaas-hoofdrapport-de-maas-meester 
Crabbé, A. 2008. Integraal waterbeleid in Vlaanderen: van fluïde naar solide. Universiteit Antwerpen, Antwerp, Belgium.

Crabbé, A., M. Wiering, and D. Liefferink. 2015. Adapting flood management to climate change: comparing policy frames and governance practices in the Low Countries. Journal of Water and Climate Change 6(1):55-70. http://dx.doi.org/10.2166/wcc.2014.018

Crotty, M. 1998. The foundations of social science: meaning and perspective in the research process. Sage, London, UK.

Dewulf, A., M. Craps, R. Bouwen, T. Taillieu, and C. Pahl-Wostl. 2005. Integrated management of natural resources: dealing with ambiguous issues, multiple actors and diverging frames. Water Science and Technology 52(6):115-124. [online] URL: http://ppw. kuleuven.be/home/english/research/wopp/marccraps/publ/dewulfcraps-et-al-2005-ambiguous-issues-and.pdf

Disco, C., 2002. Remaking "nature": the ecological turn in Dutch water management. Science, Technology, and Human Values 27 (2):206-235. http://dx.doi.org/10.1177/016224390202700202

Driessen, P. P. J., and A. A. J. De Gier. 1999. Flooding, river management and emergency legislation: experiences of the accelerated reinforcement of dikes in the Netherlands. Tijdschrift voor economische en sociale geografie $90(3): 336-342$. http://dx.doi. org/10.1111/1467-9663.00075

Gamson, W. A., and A. Modigliani. 1989. Media discourse and public opinion on nuclear power: a constructionist approach. American Journal of Sociology 95(1):1-37. http://dx.doi. $\underline{\text { org/10.1086/229213 }}$

Giddens, A. 1984. The constitution of society: outline of the theory of structuration. University of California Press, Berkeley, California, USA.

Goffman, E. 1974. An essay on the organization of experience. Frame Analysis. Northeastern University Press, Boston, Massachusetts, USA.

Hegger, D. L. T., P. P. J. Driessen, C. Dieperink, M. Wiering, G. T. T. Raadgever, and H. F. M. W. Van Rijkswick. 2014. Assessing stability and dynamics in flood risk governance. Water Resources Management 28(12):4127-4142. http://dx.doi.org/10.1007/s11269-014-0732$\underline{x}$

Hegger, D. L. T., P. P. J. Driessen, M. Wiering, H. F. M. W. Van Rijswick, Z. W. Kundzewicz, P. Matczak, A. Crabbé, G. T. Raadgever, M. H. N. Bakker, S. J. Priest, C. Larrue, and K. Ek. 2016. Toward more flood resilience: Is a diversification of flood risk management strategies the way forward? Ecology and Society 21(4):52. http://dx.doi.org/10.5751/ES-08854-210452

Huitema, D., and S. Meijerink. 2007. Understanding and managing water transitions: a policy science perspective. Paper presented at the Amsterdam Conference on Earth System Governance Amsterdam, the Netherlands, 24-26 May. [online] URL http://www.newater.uni-osnabrueck.de/caiwa/data/papers $\%$ 20session/G1/springer01-Meijerink.pdf

Huitema, D., and S. Meijerink. 2009. Policy dynamics in Dutch water management: analysing the contributions of policy entrepreneurs to policy change. Pages 349-370 in D. Huitema and S. Meijerink, editors. Water policy entrepreneurs. Edward Elgar, Cheltenham, UK. http://dx.doi.org/10.4337/9781849803366.00032
I\&M and EZ (Ministry for Infrastructure and Environment and Ministry of Economic Affairs). 2014. Deltaprogramma 2015. Werk aan de delta. De beslissingen om Nederland veilig en leefbaar te houden. Rijksoverheid, Den Haag, the Netherlands. [online] URL: https://www.rijksoverheid.nl/binaries/rijksoverheid/documenten/ begrotingen/2014/09/16/deltaprogramma-2015/deltaprogramma-2015. pdf

Johnson, C. L., S. M. Tunstall, and E. C. Penning-Rowsell. 2005. Floods as catalysts for policy change: historical lessons from England and Wales. International Journal of Water Resources Development 21(4):561-575. http://dx.doi.org/10.1080/07900620500258133

Kaufmann, M., W. Van Doorn-Hoekveld, H. K. Gilissen, and M. Van Rijswick. 2016. Analysing and evaluating flood risk governance in the Netherlands. Drowning in safety? STARFLOOD Consortium, Utrecht, The Netherlands. [online] URL: http://www.starflood.eu/documents/2016/03/wp3-nl-final-webversion. pdf

Kindler, J., J. Iwanicki , Z. W. Kundzewicz, P. Matczak, R. Miłaszewski, and J. Żelazo. 2014. Zagrożenia instytucjonalne. Nauka 1:173-195.

Kingdon, J. W. 1995. Agenda, alternatives and public policies. Harper Collins, New York, New York, USA.

Klijn, F., K. M. de Bruijn, J. Knoop, and J. Kwadijk. 2012. Assessment of the Netherlands' flood risk management policy under global change. Ambio 41(2):180-192. http://dx.doi. org/10.1007/s13280-011-0193-X

Klimaatbuffers. 2015. Reactie Coalitie Natuurlijke Klimaatbuffers Deltaprogramma 2015. Klimaatbuffers, Wageningen, The Netherlands. URL [online] http://www.klimaatbuffers.nl/reactiecoalitie-natuurlijke-klimaatbuffers-deltaprogramma-2015

Liefferink, D. 2006. The dynamics of policy arrangements: turning round the tetrahedron. Pages 45-68 in B. Arts and P. Leroy, editors. Institutional dynamics in environmental governance. Springer, Dordrecht, The Netherlands. http://dx.doi. org/10.1007/1-4020-5079-8 3

Lindekilde, L. 2014. Discourse and frame analysis: in-depth analysis of qualitative data in social movement research. Pages 195-227 in D. Della Porta, editor. Methodological practices in social movement research. Oxford University Press, Oxford, UK. http://dx.doi.org/10.1093/acprof:oso/9780198719571.003.0009

Lintsen, H. W. 2005. De revolutie van de ingenieurs. Pages 315-336 in H. W. Lintsen, editor. Made in Holland: een techniekgeschiedenis van Nederland (1800 - 2000). WalburgPers, Zutphen, The Netherlands.

Lowry, W. 2006. Potential focusing projects and policy change. Policy Studies Journal 34(3):313-335. http://dx.doi.org/10.1111/ j.1541-0072.2006.00175.x

Mahoney, J., and K. Thelen. 2009. A theory of gradual institutional change. Pages 1-37 in J. Mahoney and K. Thelen, editors. Explaining institutional change: ambiguity, agency, and power. Cambridge University Press, Cambridge, UK. http://dx. doi.org/10.1017/cbo9780511806414.003

Majewski, W. 2011. Gospodarka wodna w Polsce w latach '50 '80. Pages 19-26 in P. Światecki, editor. Stan gospodarki wodnej w 
Polsce - problematyka prawna i kompetencyjna (na przykladzie Dolnej Wisty). Zeszyty Zespołów Senackich 9/2011, Warsaw, Poland. [online] URL: http://www.senat.gov.pl/download/gfx/ senat/pl/senatzespolyinformacje/zeszyt/wodaii.pdf

Matczak, P., J. Lewandowski, A. Choryński, M. Szwed, and Z. W. Kundzewicz. 2016. Analysing and evaluating flood risk governance in Poland: looking for strategic planning in a country in transition. STAR-FLOOD Consortium, Utrecht, The Netherlands. [online] URL: http://www.starflood.eu/documents/2016/03/ wp3-poland-final-webversion.pdf

McCammon, H. J., C. S. Muse, H. D. Newman, and T. M. Terrell. 2007. Movement framing and discursive opportunity structures: the political successes of the U.S. women's jury movements. American Sociological Review 72(5):725-749. http://dx.doi. org/10.1177/000312240707200504

Meijerink, S. 2005. Understanding policy stability and change: the interplay of advocacy coalitions and epistemic communities, windows of opportunity, and Dutch coastal flooding policy 1945-2003. Journal of European Public Policy 12:1060-1077. http://dx.doi.org/10.1080/13501760500270745

Metze, T. 2014. Fracking the debate: frame shifts and boundary work in Dutch decision making on shale gas. Journal of Environmental Policy \& Planning 1-18. http://dx.doi. org/10.1080/1523908X.2014.941462

Mitchell, J. K. 2003. European river floods in a changing world. Risk Analysis 23(3):567-574. http://dx.doi.org/10.1111/1539-6924.00337

Olsson, P., L. H. Gunderson, S. R. Carpenter, P. Ryan, L. Lebel, C. Folke, and C. S. Holling. 2006. Shooting the rapids: navigating transitions to adaptive governance of social-ecological systems. Ecology and Society 11(1):18 [online] URL: http://www. ecologyandsociety.org/vol11/iss1/art18/

Organisation for Economic Co-operation and Development (OECD). 2014. Water governance in the Netherlands. Fit for the future. OECD, Paris, France.

Penning-Rowsell, E., C. Johnson, and S. Tunstall. 2006. 'Signals' from pre-crisis discourse: lessons from UK flooding for global environmental policy change? Global Environmental Change 16 (4):323-339. http://dx.doi.org/10.1016/j.gloenvcha.2006.01.006

Planologische Kernbeslissing Ruimte voor de Rivier(PKB). 2006. Planologische Kernbeslissing. Ruimte voor de Rivier. Rijksoverheid, Den Haag, the Netherlands. [online] URL: http://publicaties. minienm.nl/documenten/planologische-kernbeslissing-ruimte-voorde-rivier-dl-4-vastgest

Renn, O., A. Klinke, and M. van Asselt. 2011. Coping with complexity, uncertainty and ambiguity in risk governance: a synthesis. Ambio, 40(2):231-246. http://dx.doi.org/10.1007/ s13280-010-0134-0

Rosenthal, U. 1988. The vulnerability of the city. Pages 1-21 in L. J. Roborgh, R. Stough, and A. J. Toonen, editors. Public infrastructure revisited. Indiana University Press, Bloomington, Indiana, USA.

Rosenthal, U., and P. 't Hart, editors. 1998. Flood response and crisis management in Western Europe: a comparative analysis. Springer, Heidelberg, Germany. http://dx.doi.org/10.1007/978-3$\underline{-642-71997-4}$
Roth, D., J. Warner, and M. Winnubst. 2006. Een noodverband tegen hoog water. Waterkennis, beleid en politiek rond noodoverloopgebieden. Wageningen University, Wageningen, The Netherlands.

Schwartz, P. G. 1993. De Strategie van Rijkswaterstaat: leren bij strategische Besluitvorming. Bestuurskunde 2(1):34-41.

Sjöstedt, M. 2015. Resilience revisited: taking institutional theory seriously. Ecology and Society 20(4):23. http://dx.doi.org/10.5751/ ES-08034-200423

Snow, D., and R. Benford. 1988. Ideology, frame resonance, and participant mobilization. Pages 197-218 in B. Klandermanns, H. Kriesi, and S. Tarrow, editors. International social movement research: from structure to action. JAI Press, Greenwich, UK.

Solecki, W., and C. Rosenzweig. 2014. Climate change, extreme events, and Hurricane Sandy: from non-stationary climate to nonstationary policy. Journal of Extreme Events 1(1):1450008. http:// dx.doi.org/10.1142/S2345737614500080

Staatsbosbeheer. 2003. Lonkend Rivierenland. Visie van Staatsbosbeheer op de rivieren. Staatsbosbeheer, Utrecht, The Netherlands.

V\&W and VROM (Ministry of Transport, Public Works and Water Management and Ministry of Housing, Spatial Planning and the Environment). 2006. Beleidslijn grote rivieren. Rijksoverheid, Den Haag, The Netherlands. [online] URL: https://www.rijksoverheid.nl/binaries/rijksoverheid/documenten/ kamerstukken/2006/07/26/beleidslijn-grote-rivieren/

beleidslijn-20grote-20rivieren-20handreiking-tcm195-162030.pdf

Van den Brink, M. 2009. Rijkswaterstaat on the horns of a dilemma. Eburon, Delft, The Netherlands.

Van den Ven, G. P. 2004. Man-made lowlands: history of water management and land reclamation in the Netherlands. Stichting Matrijs, Utrecht, The Netherlands.

Van der Brugge, R., J. Rotmans, and D. Loorbach. 2005. The transition in Dutch water management. Regional Environmental Change 5(4):164-176. http://dx.doi.org/10.1007/s10113-004-0086-7

Van Eten, M. 1997. Sprookjes in rivierenland. Beleidsverhalen over wateroverlast en dijkversterking. Beleid \& Maatschappij $1: 32-43$

Van Heezik, A. 2006. Strijd om de rivieren: 200 jaar rivierenbeleid in Nederland. HNT Historische producties in samenwerking met Rijkswaterstaat, The Hague/ Haarlem, The Netherlands.

Van Herk, S., J. Rijke, C. Zevenbergen, and R. Ashley. 2015. Understanding the transition to integrated flood risk management in the Netherlands. Environmental Innovations and Societal Transitions 15:84-100. http://dx.doi.org/10.1016/j. eist.2013.11.001

Van Rijswick, H. F. M. W. and H. J. M. Havekes. 2012. European and Dutch water law. Europa Law Publishing, Groningen, The Netherlands.

Vink, M. J., D. Boezeman, A. Dewulf, and C. J. A. M. Termeer. 2013. Changing climate, changing frames: Dutch water policy frame developments in the context of a rise and fall of attention to climate change. Environmental Science \& Policy 30:90-101. http://dx.doi.org/10.1016/j.envsci.2012.10.010 
Warner, J. 2008. The politics of flood insecurity. Framing in contested river management projects. Wageningen University, Wagening, The Netherlands.

Wiering, M. A., and B. J. M. Arts. 2006. Discursive shifts in Dutch river management: 'deep' institutional change or adaptation strategy? Hydrobiologia 565(1):327-338. http://dx.doi.org/10.1007/ s10750-005-5923-2

Wiering, M. A., and P. P. J. Driessen. 2001. Beyond the art of diking: interactive policy on river management in The Netherlands. Water Policy 3(4):283-296. http://dx.doi.org/10.1016/ S1366-7017(01)00075-7

Zahariadis, N. 2014. Ambiguity and multiple streams. Pages 25-58 in P. A. Sabatier and C. M. Weible, editors. Theories of the policy process. Westview, Boulder, Colorado, USA. 